\title{
ANALISIS PENGETAHUAN IBU HAMIL DENGAN PERENCANAAN PERSALINAN DAN PENCEGAHAN KOMPLIKASI
}

\author{
Rahmi Padlillah $^{1}$, Mega Octamelia ${ }^{2}$, Doris Noviani ${ }^{3}$ \\ 1,2,3, Fakultas Ilmu Kesehatan Universitas Borneo Tarakan \\ *Email: megaoctamelia@gmail.com
}

\begin{abstract}
Abstrak
Kematian ibu di Indonesia yaitu sebesar 359/100.000 kelahiran hidup. Hal ini dapat dicegah melalui beberapa cara yaitu melalui perencanaan persalinan di tempat kesehatan, ditolong oleh tenaga kesehatan, persiapan biaya maupun dukungan keluarga. Tujuan penelitian ini yaitu menganalisis pengetahuan ibu hamil tentang faktor resiko tinggi dan komplikasi persalinan terhadap perencanaan persalinan. Desain penelitian yang digunakan dalam penelitian ini adalah survey analitik dengan pendekatan cross sectional. sampel dalam penelitian ini sebanyak 63 responden. Pengumpulan data dilakukan bulan Desember 2017. Instrumen yang digunakan untuk mengumpulkan data adalah kuesioner. Hasil uji statistik chi square diperoleh $p$ value $=0,048(\mathrm{p}>0,05)$ yang berarti ada hubungan antara pengetahuan ibu hamil dengan perencanaan persalinan dan pencegahan komplikasi. Saran untuk peneliti selanjutnya menambah variabel penelitian terkait perencanaan persalinan dan pencegahan komplikasi.
\end{abstract}

Kata kunci : Pengetahuan, Perencanaan Persalinan Dan Pencegahan Komplikasi

\section{Abstract}

Analysis Of Knowledge Of Pregnant Women With Labor Planning And Prevention Of Complications. Maternal mortality in Indonesia is equal to 359/100,000 live births. This can be prevented through several ways, like planning give birth in a health place, assisted by health workers, preparation of costs and family support. The purpose of this study was to analyze the knowledge of pregnant women with planning and prevention complication of childbirth. The research design used in this study was an survey analytical with cross sectional approach. Sample in this study were 63 respondents. Data was collected on December 2017. The instrument was used to collect data is a questionnaire. The results of the chi square statistical test obtained $p$ value $=0.048(p>0.05)$ which means there is relation between the knowledge of pregnant women with planning and prevention complication of childbirth. Recommendation for the next researcher adds research variables related to planning and prevention complication of childbirth.

Keywords: knowledge, planning and prevention complication of childbirth

\section{Pendahuluan}

Data World Health Organization (WHO) pada tahun 2013 menunjukkan bahwa ada 800 wanita meninggal karena komplikasi pada kehamilan dan persalinan. Penyebab kematian langsung menurut World Health Organization (WHO) diantaranya adalah perdarahan, infeksi, hipertensi dalam kehamilan, aborsi yang tidak aman serta partus macet. Menurut SDKI (2012) AKI di Indonesia sebesar 359/100.000 kelahiran 
hidup. Ada beberapa faktor penyebab langsung kematian ibu diantaranya adalah preeklamsia/eklamsia, pendarahan, infeksi, dan penyakit jantung sedangkan faktor tidak langsung kematian yaitu rendahnya tingkat sosial, ekonomi, tingkat pendidikan, kedudukan dan peran perempuan, sosial budaya serta transportasi (Departemen Kesehatan Republik Indonesia, 2009).

Komplikasi yang sering terjadi pada ibu yaitu jarak kehamilan, penyakit ibu, riwayat komplikasi obstetri sebelumnya, penolong persalinan serta tempat persalinan (Diana dkk, 2013). Menurut hasil penelitian dari Serilaila dkk (2013) komplikasi obstetri lebih banyak terjadi pada daerah yang berada di desa daripada di kota. Hal ini bisa disebabkan oleh jumlah fasilitas layanan kesehatan yang kurang serta pemahaman masyarakat yang kurang tentang resiko yang akan terjadi jika melahirkan di usia terlalu muda atau terlalu tua.

Kematian pada kehamilan dan persalinan dapat dicegah melalui cara meningkatkan kualitas pelayanan Kesehatan Ibu Dan Anak (KIA). Pelayanan KIA ini dapat dilakukan diantaranya melalui pertolongan persalinan oleh tenaga kesehatan, tempat persalinan yang aman, biaya serta dukungan keluarga.

Pelayanan tersebut dapat terlaksana jika ibu hamil memilki pengetahuan yang cukup mengenai perencanaan persalinan yang aman maupun pencegahan kompikasi. Tingkat pengetahuan pada seseorang ini bisa didapatkan dari hasil tahu oleh indra terhadap suatu objek baik dari media massa maupun media elektronik (Notoadmodjo, 2010). Melalui pengetahuan ini masyarakat diharapkan dapat membuat perencanaan persalinan dan pencegahan komplikasi secara lebih dini. Tujuan penelitian ini yaitu menganalisis pengetahuan ibu hamil dengan perencanaan persalinan dan komplikasi.

\section{Metode}

Desain penelitian yang digunakan dalam penelitian ini adalah survey analitik dengan pendekatan cross sectional. Populasi dalam penelitian ini adalah seluruh ibu hamil di wilayah kerja Puskesmas Sebengkok. Sampel yang diambil yaitu ibu hamil yang berkunjung ke Puskesmas Sebengkok periode bulan Desember 2017 yaitu 63 responden. Instrumen yang digunakan untuk mengumpulkan data adalah kuesioner. Kuesioner berisi tentang kehamilan resiko tinggi dan komplikasi untuk mengukur variabel independen pengetahuan. Kuesioner yang berisi tentang perencanaan persalinan, penolong persalinan, persiapan kendaraan, biaya persalinan, dan persiapan donor darah jika dibutuhkan untuk mengukur 
variabel dependen perencanaan persalinan dan komplikasi.

Pengukuran validitas instrumen dalam penelitian ini dengan cara mengkorelasikan skor yang diperoleh pada masing-masing item pertanyaan. Uji validitas menggunakan metode korelasi pearson dengan bantuan SPSS dan dinyatakan valid karena $r$ hitung lebih besar dari $r$ tabel $(\alpha=0,05)$. Uji reliabilitas menggunakan rumus alpha cronbach dan dinyatakan reliabel karena $\mathrm{r}$ alpha lebih besar dari $r$ tabel.

Penelitian ini didapatkan dengan mengisi dan menandatangani lembar persetujuan (informed consent), menjaga kerahasiaan, serta mempertimbangkan aspek keadilan responden. Analisis univariat menggunakan jumlah dan presentase. Analisis bivariat menggunakan uji chi square.

\section{Hasil}

Pada penelitian ini di dapatkan hasil sebagai berikut ;

Tabel.1 Pendidikan Responden

\begin{tabular}{ccc}
\hline Pendidikan & $\begin{array}{c}\text { Jumlah } \\
(\mathbf{n})\end{array}$ & $\begin{array}{c}\text { Persentase } \\
(\boldsymbol{\%})\end{array}$ \\
\hline SD & 4 & 6,3 \\
SMP & 16 & 25,4 \\
SMA & 31 & 49,2 \\
PT & 12 & 19 \\
\hline
\end{tabular}

Berdasarkan tabel.1 menunjukkan bahwa sebagian besar pendidikan responden ibu hamil yaitu SMA 49,2\%.
Tabel.2 Pengetahuan Responden

\begin{tabular}{ccc}
\hline Pengetahuan & $\begin{array}{c}\text { Jumlah } \\
(\mathbf{n})\end{array}$ & $\begin{array}{c}\text { Persentase } \\
(\mathbf{\%})\end{array}$ \\
\hline Tinggi & 25 & 39,7 \\
Sedang & 30 & 47,6 \\
Kurang & 8 & 12,7 \\
\hline
\end{tabular}

Berdasarkan tabel.2 menunjukkan bahwa sebagian besar responden ibu hamil memiliki tingkat pengetahuan sedang yaitu $47,6 \%$.

Tabel.3 Perencanaan Persalinan dan Pencegahan Komplikasi

\begin{tabular}{ccc}
\hline Pengetahuan & $\begin{array}{c}\text { Jumlah } \\
(\mathbf{n})\end{array}$ & $\begin{array}{c}\text { Persentase } \\
(\boldsymbol{\%})\end{array}$ \\
\hline Baik & 25 & 39,7 \\
Kurang & 38 & 60,3 \\
\hline
\end{tabular}

Berdasarkan tabel.3 menunjukkan bahwa sebagian besar responden ibu hamil memiliki perencanaan persalinan dan pencegahan komplikasi yang kurang yaitu $60,3 \%$.

Tabel.4 Tabulasi Silang Pengetahuan Ibu Hamil Terhadap Perencanaan Persalinan dan Pencegahan Komplikasi

\begin{tabular}{|c|c|c|c|}
\hline \multirow[t]{3}{*}{ Pengetahuan } & \multicolumn{2}{|c|}{$\begin{array}{c}\text { Perencanaan } \\
\text { Persalinan dan } \\
\text { Pencegahan } \\
\text { Komplikasi }\end{array}$} & \multirow[t]{3}{*}{ Jumlah } \\
\hline & Baik & Kurang & \\
\hline & $\mathbf{n}$ & $\mathbf{n}$ & \\
\hline Tinggi & 11 & 14 & 25 \\
\hline Sedang & 14 & 16 & 30 \\
\hline Rendah & 0 & 8 & 8 \\
\hline Jumlah & 25 & 38 & 63 \\
\hline
\end{tabular}

Berdasarkan tabel.4 hasil uji statistik chi square diperoleh $p$ value $=0,048(\mathrm{p}>0,05)$. Hal ini menunjukkan adanya hubungan antara pengetahuan ibu hamil dengan perencanaan persalinan dan pencegahan komplikasi. 


\section{Pembahasan}

Berdasarkan hasil penelitian ini didapatkan pendidikan responden sebagian besar sebagian besar pendidikan responden ibu hamil yaitu SMA 49,2\%. Pendidikan merupakan salah satu faktor internal yang dapat mempengaruhi pengetahuan. Pernyataan ini sesuai dengan hasil penelitian Putri (2012) yang menyatakan bahwa ada hubungan positif antara tingkat pendidikan terhadap tingkat pengetahuan. Dalam penelitian ini sebagian besar responden didapatkan memiliki tingkat pengetahuan sedang yaitu $47,6 \%$. Menurut Nursalam (2011) tingkat pendidikan dapat mempengaruhi tingkat pengetahuan seseorang, tetapi bukan berarti pengetahuan hanya dipengaruhi oleh pendidikan. Beberapa faktor lain yang dapat mempengaruhi pengetahuan diantaranya adalah pengalaman, informasi, lingkungan serta sosial budaya.

Hasil penelitian ini juga didapatkan sebagian besar responden ibu hamil memiliki perencanaan persalinan dan pencegahan komplikasi yang kurang yaitu $60,3 \%$. Perencanaan persalinan dan pencegahan komplikasi ini terdiri dari pemilihan penolong persalinan, tempat persalinan yang aman, persiapan biaya serta persiapan adanya kendaraan yang akan digunakan jika terjadi komplikasi pada kehamilan maupun persalinan.
Penelitian Sari dkk mengungkapkan bahwa tingkat pendidikan merupakan salah satu variabel yang paling dominan dengan kejadian risiko kehamilan 4T (terlalu tua, terlalu muda, terlalu banyak dan terlalu dekat). Ibu hamil dengan pendidikan rendah (SD ke bawah) memiliki peluang 1,4 kali dalam mengalami risiko pada masa kehamilannya (Sari dkk, 2014).

Hasil uji chi square didapatkan $p$ value $=$ $0,048(\mathrm{p}>0,05)$ sehingga ada hubungan antara pengetahuan ibu hamil terhadap perencanaan persalinan dan pencegahan komplikasi di wilayah kerja Puskesmas Sebengkok. Hal ini sesuai dengan hasil penelitian dari Astuti dkk (2014) yang menyatakan bahwa pengetahuan mempengaruhi pengambilan keputusan saat melakukan pemilihan penolong persalinan. Penelitian ini juga sesuai dengan penelitian dari Putri (2015) yang menyatakan bahwa responden ibu yang mempunyai pengetahuan kurang akan memilih tempat persalinan seperti di rumah daripada responden yang memiliki pengetahuan baik.

Penelitian Amilda dan Palarto (2010) juga mendukung hasil penelitian ini karena didapatkan adanya hubungan yang bermakna antara tingkat pengetahuan dengan pemilihan pertolongan persalinan oleh dukun bayi. Keterbatasan penelitian ini adalah waktu penelitian yang kurang memadai dan kurangnya variabel penelitian untuk 
menentukan perencanaan persalinan dan pencegahan komplikasi pada ibu hamil.

\section{Kesimpulan}

Berdasarkan hasil uji statistik pengetahuan pada ibu hamil tentang faktor resiko tinggi dan komplikasi persalinan terhadap perencanaan persalinan dan pencegahan komplikasi. Saran bagi peneliti selanjutnya diharapkan untuk memperpanjang waktu dalam penelitian dan menambahkan variabel penelitian.

\section{Referensi}

Amilda, N.L. dan Palarto, B. (2010). FaktorFaktor Yang Berhubungan Dengan Pemilihan Pertolongan Persalinan Oleh Dukun Bayi. Jurnal UNDIP

Astuti, A.P, Kartasurya, M.I, \& Sriatmi, A. (2014). Analisis Alasan Pemilihan Penolong Persalinan oleh Ibu Bersalin di Kabupaten Semarang. Jurnal Manajemen Kesehatan Indonesia Volume 02, Nomor 3, 254-260.

Diana, Sukandar, H. Dan Handono, B. (2013). Analisis Faktor-Faktor Yang Berhubungan Dengan Komplikasi Obstetri Ibu Dan Bayi Di Kecamatan Parongpong Kabupaten Bandung Barat. UNPAD, 1-18.
Departemen Kesehatan Republik Indonesia. (2009) Pedoman Program Perencanaan Persalinan dan Pencegahan Komplikasi Dengan Stiker : Dalam Rangka Mempercepat Penurunan AKI, Jakarta: Departemen Kesehatan RI.

Mardela, A.P. (2012). Rencana Pemilihan Penolong Dan Tempat Persalinan Ibu Hamil Setelah Diberikan Pendidikan Kesehatan Tentang Persiapan Persalinan Aman. Jurnal UNPAD, Volume 1, Nomor 1, 781.

Notoatmodjo, S. (2010) Ilmu Kesehatan Masyarakat, Jakarta : Rineka Cipta.

Nursalam. (2011). Konsep Dan Penerapan Metodologi Penelitian Ilmu Keperawatan. Jakarta : Salemba Medika.

Putri, K.D.P. (2012). Pengaruh Tingkat Pendidikan, Pengetahuan, Sikap dan Terpaan Iklan Layanan Masyarakat KB versi Shireen Sungkar dan Tengku Wisnu di TV Terhadap Perilaku KB pada Wanita atau Pria dalam Usia Subur. Jurnal Interaksi, Volume 1, Nomor 1, 4656.

Putri, M.D. (2016). Faktor-Faktor Yang Berhubungan Dengan Pemilihan Tempat Persalinan Tahun 2015 (Studi Di Kecamatan Sarolangun Kabupaten Sarolangun Jambi), Jurnal Kesehatan 
Masyarakat (e-Journal), Volume 4, Nomor 2, 55-67.

Prawirohardjo, S. (2008). Buku Acuan Nasional Pelayanan Kesehatan Maternal Neonatal. Jakarta : Yayasan Bina Pustaka.

Reeder, S.J. 2011. Keperawatan Maternitas : Kesehatan Wanita, Bayi \& Keluarga. Alih bahasa: Yati Afiyanti, Imami Nur Rachmawati, Sri Djuwitaningsih. Jakarta : EGC.

Serilaila, Yaniarti, S. Kurniawati, P.S. Simbolon, D. (2013). Determinan Komplikasi Obstetri Di Indonesia
(Analisis Data SDKI 2012). Jurnal Skala Kesehatan Politeknik Kesehatan Banjarmasin Vol.9, No.2, Juli 2018

Sari, P.H., Hapsari, D., Dharmayanti, I., dan Kusumawardani, N. (2010). FaktorFaktor Yang Berpengaruh Terhadap Risiko Kehamilan 4 Terlalu (4-T) Pada Wanita Usia 10-59 Tahun. (Analisis Riskesdas 2010). Jurnal Media Penelitian dan Pengembangan Kesehatan, Volume 24, Nomor 3, 143152. 